\title{
Regina TV Tower Mortality
}

May 11-12, 1962

by Robert W. Nero, University of Saskatchewan, Regina.

Three instances of mass bird mortalities at TV towers have so far been reported for Saskatchewan, involving 33,94 and 113 collision casualties (Blue Jay, 17: 142-143; 19: 160-164). These kills occurred during fall migration, from September 3 to September 22. The present note describes a mortality which occurred during spring migration.

On May 12, 1962, a party of five birders, participating in the Regina Annual Spring Bird Census (Blue Jay, 20: 115, 131), checked the grounds at the CKCK TV tower and discovered that a kill had occurred. This group included Herb and Ruth Tempel, Loraine MacPherson, Elsie Cheesman and Fern Lawrence. We are indebted to these people for their interest and co-operation in providing this information. These five people searched the grounds at the station early in the morning for one hour, recovering 31 specimens of five species (Table 1, May 12). Early the following morning my wife and I painstakingly searched the area again, including the various roofs of the station buildings, and found an additional 28 specimens of five species (Table 1, May 13), mainly north and west of the tower. All of these birds seemed to us to have been killed at the same time as the sample picked up on May 12. It is of interest to note that, in spite of the low numbers, the two samples are remarkably similar. We should point out that the station grounds included some very muddy and dense weedy sections; when I queried the Tempels they said that they had not covered these areas and, in fact, had even seen some birds lying in the mud and had passed them by. Accordingly, these two samples have been combined to make a total of 51 individuals of six species. Thrushes of two species make up 81 per cent of the total kill, a relatively high proportion. These two thrushes were abundant throughout the Regina district on May 12, 400 Swainson's Thrushes and 30 Graycheeked Thrushes being reported by the 1! teams in the field. Lower numiers for the latter species may be due in part to a greater difficulty of identification.

This spring kill was undoubtedly the result of the occurrence of large numbers of migrants from the south coinciding with bad weather during the night of May 11 and the early morning of May 12. John F. Quine, Meteorological Officer, Regina Weather Office, kindly provided the following information which describes these unfavorable conditions. May 11: 6.00 p.m.-ceiling 800 feet, light drizzle, wind E-SE at $14 \mathrm{mph}$.; 9:00 p.m. - ceiling 300 feet visibility one mile, wind E-SE at $18 \mathrm{mph} ; 12: 00$ p.m. - ceiling 300 feet, fog, visibility four miles, wind SE at $18 \mathrm{mph}$; May 12: 1:00 a.m.-ceiling 200 feet, light drizzle, fog, visibility four miles, wind SE at seven mph.; 3:00 a.m.-ceiling 200 feet and broken, light drizzle, fog, visibility four miles, wind S-SE at eight mph.; 4:00 a.m.-overcast, light drizzle, fog, visibility three miles, wind S-SE at $12 \mathrm{mph}$.; gradually improving conditions; 6:00 a.m.-ceiling 200 feet, broken clouds, light rain, visibility eight miles, wind SW at 11 $\mathrm{mph}$. The temperature throughout this period was constant at about $45^{\circ}$ F. Fair and sunny weather prevailed from mid-morning on May 12, overnight and through May 13.

Migrants borne in on favorable winds are forced down by low clouds, rain and fog, and under such conditions they may blunder into high obstructions. TV towers, with their lights, numerous supporting wires, etc., seem to pose a special obstacle to nocturnal migrants. It may be expected that a duplication of the above conditions will produce other kills, hence persons who live close to TV towers ought to make a special effort to check and record the occurrence, or the lack of occurrence, of mortalities. In the next few years we can expect to see a considerable increase in the numbers of towers erected in the province. These should all be watched carefully.

The Tempel party also found a pair of Lapland Longspurs on the morning of May 12 at a radio tower on old No. 
1 Highway, east of Regina, no doubt casualties of the same bad weather. On May 13 single specimens of three additional species-House Sparrow, Tree Sparrow and Snow Buntingwere found by us on the CKCK station roof, out these were all one to fcur weeks old.

One Swainson's Thrush, among those found by the Tempel party, exhibited random partial albinism. White feathers occurred irregularly in the plumage as follows: on the top of the head, on the nape and back of the lower neck, on the sides of the head at the angle of the jaws, a lesser covert on the right: wing, in the scapulars and on the back and rump. Areas which were especially affected were the nape and sides of the head (29 feathers), and the rump (10 feathers). $\dot{A}$ total of 48 white feathers was counted; in all cases, the whole feather was pure white. The bird was apparently otherwise normal.

\section{TABLE I-Birds recovered}

1. Swainson's Thrush

2. Gray-cheeked Thrush

3. Blackpoll Warbler

4. Savannah Sparrow

5. Clay-colored Sparrow

6. White-crowned Sparrow Totals

\begin{tabular}{cccc} 
at & TV tower, May & 12-May \\
May 12 & May 13 & Combined \\
& 14 & 9 & 23 \\
& 11 & 14 & 25 \\
& 3 & 2 & 5 \\
& 2 & 2 & 4 \\
& -1 & 1 & 1 \\
& 1 & - & 1 \\
\hline
\end{tabular}

13,1962

Male Female 158

$14 \quad 11$

41

$-\quad \frac{1}{1}$

\begin{tabular}{l}
1 \\
$-\quad 1$ \\
\hline
\end{tabular}

\section{Fall Migration TV Tower Kills, 1962}

by Fred Lahrman, Sask. Museum of Natural History

The TV towers at Regina, Moose Jaw and Caron were checked on selected weekends during September and October by myself and other members of the staff of the Saskatchewan Museum of Natural History. In summarizing the kills noted on these occasions, we were once more struck by the fact that the species represented and the numbers involved in the kill did not necessarily coincide with those most commonly reported for the same dates by persons observing the fall migrants that normally come down in the area.

On September 7, 1962, I visited the CICK TV tower at Regina with A. Swanston, R. Carson and F. Bard, and recovered 52 birds of 14 species, as follows: Red-eyed Vireo (10), Philadelphia Vireo (1), Warbling Vireo (1), Tennessee Warbler (4), Yellow Warbler (3), Bay-breasted Warbler (5), Blackpoll Warbler (2), Palm Warbler (1), Ovenbird (13), Northern Waterthrush (4), Connecticut Warbler (3), Yellowthroat (1), Wilson's Warbler (3), House Sparrow (1). The number of Baybreasted Warblers (5) among the warblers found on this date fits in with the three birds of this species, formerly regarded as very rare in Regina, which were recovered by $R$. W. Nero at the Regina TV tower on
September 3, 1961 (see Blue Jay, 19:161).

The following day, September 8, Mr. Bard and I checked the TV tower at Moose Jaw, finding 1 Sora and 1 Savannah Sparrow.

On the weekend of October 6-7, two visits were paid to the CKCK TV tower at Regina when the species recovered of course differed noticeably from those reported a month previously. The most interesting find was a Yellow Rail which I picked up on October 7 and reported to Margaret Belcher as a new record for the check-list of the birds of Regina. In addition, we recovered Common Snipe ( 2 on Oct. 7), Swainson's Thrush (2 on Oct. 6; 1 on Oct. 7), Grey-cheeked Thrush (1 on Oçt. 7), Orangecrowned Warbler (5 on Oct. $6 ; 3$ on Oct. 7), Myrtle Warbler (3 on Oct. $6 ; 1$ on Oct. 7), Yellowthroat ( 1 on Oct. 6), Savannah Sparrow (3 on Oct. 6), Vesper Sparrow (1 on Oct. 7).

At Caron, five visits were made to the TV tower in September, with the following recoveries: Sept. 9-Coot (1), Swainson's Thrush (1); Sept. 12 -Sora (2), Chestnut-sided Warbler (1) (my first fall migration record); Sept. 14-Red-eyed Vireo (1); Sept. 15-Ovenbird (1); Sept. 30-Sparrow Hawk (1) (dead for several days). 